\title{
ДОКУМЕНТУВАННЯ РЕЗУЛЬТАТІВ ДІЯЛЬНОСТІ ВНУТРІШНЬОГО АУДИТУ БАНКУ
}

\section{DOI: 10.32620/cher.2019.2.06}

\begin{abstract}
Постановка проблеми. у статті розглянуто необхідність документування аудиторського завдання внутрішніх аудиторів банку та організації даного процесу підрозділом внутрішнього аудиту. Mema cmammi - проаналізувати новітні вимоги до документування результатів роботи внутрішнього

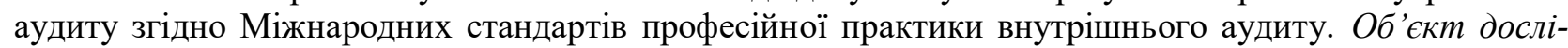
дження - документи про виконання завдань з надання впевненості внутрішніх аудиторів. Методи, використані в дослідженні: аналізу та синтезу, індукції, методи наукового пізнання. Гіпотеза дослідження: професійне судження сформоване на задокументованих аудиторських доказах для осіб, які використовують оцінку результатів діяльності підрозділу внутрішнього аудиту для конкретних цілей. Виклад основного матеріалу. За результатами аналізу визначено документи, які використовує внутрішній аудитор з метою обгрунтування висновків за результатами аудиторського дослідження. На основі організації процесу документування виділено та згруповано документи, які відповідають виконанню завдання на кожному етапі внутрішнього аудиту. Оригінальність та практичне значення дослідження полягає в розробці пакету документів, які покращать процес організації та виконання завдання внутрішнього аудиту та будуть становити доказову базу при формуванні результатів в аудиторському звіті. Висновки дослідження: встановлено, що здійснення документування забезпечує отримання аудиторських доказів для розробки рекомендацій щодо мінімізації рівня ризиків та управління ними, покращення системи внутрішнього контролю банківської діяльності та сприяння удосконаленню корпоративного управління.
\end{abstract}

Ключові слова: внутрішній аудит, Міжнародні стандарти професійної практики внутрішнього аудиту, підрозділ внутрішнього аудиту, корпоративне управління, управління ризиками, система внутрішнього контролю, аудиторські докази.

\section{DOCUMENTING OF AN ASSURANCE ENGAGEMENT OF INTERNAL AUDITORS OF THE BANK}

Formulation of the problem. The article deals with the need to document of an assurance engagement of internal auditors of the bank and the organization of this process by the internal audit department. The purpose of the research is to analyze the latest requirements for documenting the results of the internal audit work in accordance with the International Standards for the Professional Practice of Internal Auditing. The object of research - the documents of an assurance engagement of internal auditors. The methods used of the research: analysis and synthesis, induction, methods of scientific knowledge. The hypothesis of research: a professional judgment is formed on documented provides receiving audit evidence for individuals who use an assessment of the activities of the internal audit department for specific purposes. The statement of basic material: the results of the analysis identify the documents used by the internal auditor to substantiate the findings of the audit findings. On the basis of the organization of the documentation process, the documents that selected to the implementation of an assurance engagement of internal auditors at each stage of the internal audit are selected and grouped. The originality and practical significance of the research is to develop of documents that will improve the organization and execution of an assurance engagement of internal auditors and will provide an evidence base for the results in the audit report. Conclusions of the research. Established that the implementation of documentation provides receiving audit evidence for the development of recommendations for decrease of risk and risk management, improving the system of internal control of banking activities and promoting the improvement of governance.

Key words: internal audit, International Standards for the Professional Practice of Internal Auditing, internal audit department, governance, risk management, the system of internal control, audit evidence.

${ }^{1}$ Долінська Оксана Михайлівна, аспірант кафедри «Облік і оподаткування», ДВНЗ «Університет банківської справи», м. Київ, Україна.

Dolinska Oksana, Ph.D. student of Accounting and taxation Department Banking University, Kyiv, Ukraine.

ORCID ID: 0000-0003-2939-6435

e-mail: dolinska_om@ukr.net 


\section{ДОКУМЕНТИРОВАНИЕ РЕЗУЛЬТАТОВ ДЕЯТЕЛЬНОСТИ ВНУТРЕННЕГО АУДИТА БАНКУ}

Постановка проблемы. В статье рассмотрена необходимость документирования аудиторского задания внутренних аудиторов банка и организации данного процесса подразделением внутреннего аудита. Цель статьи - проанализировать новые требования к документированию результатов работы внутреннего аудита согласно Международным стандартам профессиональной практики внутреннего аудита. Объект исследования - документы о выполнении заданий по предоставлению уверенности внутренних аудиторов. Методы, использованные в исследовании: анализа и синтеза, индукции, методы научного познания. Гипотеза исследования: профессиональное суждение сформировано на документированных аудиторских доказательствах для лиц, использующих оценку результатов деятельности подразделения внутреннего аудита для конкретных целей. Изложение основного материала: по результатам анализа определены документы, которые использует внутренний аудитор с целью обоснования выводов по результатам аудиторского исследования. На основе организации процесса документирования выделено и сгруппированы документы, соответствующие выполнению заданий на каждом этапе внутреннего аудита. Оригинальность и практическое значение исследования заключается в разработке пакета документов, которые улучшат процесс организации и выполнения задания внутреннего аудита и будут составлять доказательную базу при формировании результатов в аудиторском отчете. Вывводы исследования: установлено, что осуществление документирования обеспечивает получение аудиторских доказательств для разработки рекомендаций по минимизации уровня рисков и управления ими, улучшение системы внутреннего контроля банковской деятельности и содействие совершенствованию корпоративного управления.

Ключевые слова: внутренний аудит, Международные стандарты профессиональной практики внутреннего аудита, подразделение внутреннего аудита, корпоративное управление, управление рисками, система внутреннего контроля, аудиторские доказательства.

Постановка проблеми. В сучасних умовах посилюється значення внутрішнього аудиту як інструменту забезпечення стабільного розвитку банку. Функція внутрішнього аудиту повинна відповідати Міжнародним стандартам професійної практики внутрішнього аудиту, що забезпечується через призму своєчасного та систематичного ризикорієнтованого підходу у сприянні удосконаленні корпоративного управління, контролю та управління ризиками. Новітні погляди внутрішніх аудиторів для стратегічних та оперативних рішень формують цінність та довіру до них і забезпечують ефективне управління діяльністю банку.

Аналіз останніх досліджень та публікацій. Наукову проблематику досліджували такі вчені, як Т. О. Каменська [2], О. І. Скаско [10], Н. М. Проскуріна [8], С. М. Петренко [6], Т. І. Сафонов [9], М. А. Маркевич [3], М. С. Письменна [7], Г. М. Білокінь [1], Філозоп [13], К. С. Сурніна [12]. Цілісної концепції організаційних засад документального ведення завдання з внутрішнього аудиту у банку не розроблено. Недосконалість інформаційного забезпечення загострює питання документального відображення результатів роботи внутрішнього аудиту банку. Питання потребує дослідження теоретичних по- нять та організаційних вимог щодо документального забезпечення виконання аудиторського завдання.

Мета статті полягає у дослідженні новітніх вимог Міжнародних стандартів професійної практики внутрішнього аудиту щодо документування на усіх етапах виконання завдання внутрішніми аудиторами для формування доказової бази та відображення в аудиторському звіті результатів перевірки.

Виклад основного матеріалу дослідження. Внутрішній аудит у банку проводиться у відповідності до Міжнародних стандартів професійної практики внутрішнього аудиту (далі - МСППВА) редакції 2017 року [5], переклад яких здійснений Всеукраїнською громадською організацією «Інститут внутрішніх аудиторів України». Ефективно виконати аудиторське завдання допоможе правильна організація робочого процесу на основних етапах внутрішнього аудиту. Для отримання аудиторських доказів внутрішній аудитор зазначає відповідні робочі записи у своїх робочих документах, які є додатками до його звіту за результатами виконаного аудиторського завдання. Згідно глосарію МСППВА під аудиторським завданням розуміється «конкретне завдання внутрішнього аудиту, задача або перевірка, такі, як 
внутрішній аудит, перевірка самооцінки контролю, розслідування фактів шахрайства або надання консультацій. Завдання може включати різноманітні задачі або діяльність, що спрямовані на досягнення ряду пов'язаних цілей». Структура МСППВА складається 3 стандартів якісних характеристик (Attribute Standards), які описують специфіку організації роботи осіб, що задіяні у внутрішньому аудиті та стандартів діяльності (Performance Standards), які зазначають безпосередню професійну спрямованість для ефективного виконання аудиторського завдання, а також функціонування підрозділу внутрішнього аудиту.

Стандарти якісних характеристик (Attribute Standards) маю наступну структуру:

- 1000 - Цілі, повноваження та обов'язки;

- 1010 - Визнання обов'язкових керівництв у статуті внутрішнього аудиту;

- 1100 - Незалежність і об'єктивність;

- 1110 - Організаційна незалежність;

- 1111 - Пряма взаємодія з радою;

- 1112 - Функції керівника внутрішнього аудиту, які не стосуються діяльності внутрішнього аудиту;

- 1120 - Індивідуальна об'єктивність;

- 1130 - Обмеження незалежності та об'єктивності;

- 1200 - Професійна компетентність та належна ретельність;

- 1210 - Професійна компетентність;

- 1220 - Належна професійна ретельність;

- 1230 - Постійний професійний розвиток;

- 1300 - Програма забезпечення та підвищення якості;

- 1310 - Вимоги до програми забезпечення та підвищення якості;

- 1311 - Внутрішні оцінки;

- 1312 - Зовнішні оцінки;

- 1320 - Звітність за програмою забезпечення та підвищення якості;

- 1321 - Використання фрази «Відповідає Міжнародним стандартам професійної практики внутрішнього аудиту»;

- 1322 - Розкриття інформації про невідповідність.
Внутрішній аудит потребує ретельної організації. Ефективно здійснити аудит допоможе виділення його основних етапів. Аудиторські докази формуються на всіх його етапах. 3 метою врахування вимог стандартів діяльності (Performance Standards) розглянемо детально, яких з них потрібно дотримуватись на основних етапах внутрішнього аудиту при формування аудиторських доказів (табл. 1).

Між цими стандартами має бути взаємоув'язка та взаємозалежність для надання послуг 3 внутрішнього аудиту. Одночасно стандарти якісних характеристик та стандарти діяльності доповнюють стандарти практичного застосування (Implementation Standards), які деталізують окремі аудиторські завдання щодо їх специфіки у виконанні вимог надання безумовної впевненості та гарантії виконання такої діяльності. Такі стандарти мають відмітку «А», що відноситься до аудиторських послуг та відмітку «К», що належить до проведення консультаційних послуг. Відповідна літера стоїть після чотиризначного номеру стандарту. Кожен банк з метою побудови та подальшого удосконалення ефективного підрозділу внутрішнього аудиту, забезпечення якісного аналізу й оцінки ефективності системи внутрішнього контролю приймає Міжнародні стандарти професійної практики внутрішнього аудиту в якості своїх внутрішніх стандартів, якими керуються при виконанні вимог щодо професійної організації та практичної діяльності внутрішнього аудиту. До прийнятих стандартів можуть вноситись уточнюючі корективи для одночасного дотримання законодавчих вимог, а також врахування міжнародних вимог. На кожному з трьох основних етапів ведеться документування результатів діяльності, що дозволяє досягати цілей аудиторського завдання та загалом функції внутрішнього аудиту.

Етап планування характеризується організацією роботи підрозділу внутрішнього аудиту та планування аудиторського завдання. Розробляється ризик-орієнтований план для забезпечення функції внутрішнього аудиту, який подається на затвердження вищому виконавчому керівництву та раді банку.

Здійснюються запити до структурних підрозділів щодо необхідної інформації про об’єкти, які будуть підлягати перевірці. 
Т а б ли ц я 1

Відповідність Міжнародних стандартів професійної практики внутрішнього аудиту етапам аудиторського завдання

\begin{tabular}{|c|c|}
\hline Етапи & Міжнародні стандарти професійної практики внутрішнього аудиту \\
\hline Планування & $\begin{array}{l}2000 \text { - Управління функцією внутрішнього аудиту } \\
2010 \text { - Планування } \\
2020 \text { - Надання інформації та затвердження } \\
2030 \text { - Управління ресурсами } \\
2040 \text { - Політика й процедури } \\
2050 \text { - Координація діяльності та покладання на роботу } \\
2060 \text { - Звітування вищому виконавчому керівництву та раді } \\
2070 \text { - Зовнішній постачальник послуг та відповідальність організації за } \\
\text { внутрішній аудит } \\
2100 \text { - Сутність роботи внутрішнього аудиту } \\
2110 \text { - Корпоративне управління } \\
2120 \text { - Управління ризиками } \\
2130 \text { - Контроль } \\
2200 \text { - Планування завдання } \\
2201 \text { - Фактори, що необхідно враховувати при плануванні } \\
2210 \text { - Цілі завдання } \\
2220 \text { - Обсяг завдання } \\
2230 \text { - Розподіл ресурсів завдання } \\
2240 \text { - Робоча програма завдання }\end{array}$ \\
\hline $\begin{array}{c}\text { Виконання } \\
\text { аудиторського } \\
\text { завдання }\end{array}$ & $\begin{array}{l}2300 \text { - Виконання завдання } \\
2310 \text { - Збір інформації } \\
2320 \text { - Аналіз та оцінка } \\
2330 \text { - Документування інформації } \\
2340 \text { - Контроль за виконанням завдання }\end{array}$ \\
\hline Результативний & $\begin{array}{l}2400 \text { - Звітування результатів } \\
2410 \text { - Критерії звітування } \\
2420 \text { - Якість звітів } \\
2421 \text { - Помилки та упущення } \\
2430 \text { - Використання фрази «Виконано у відповідності до Міжнародних } \\
\text { стандартів професійної практики внутрішнього аудиту» } \\
2431 \text { - Розкриття інформації про невідповідність } \\
2440 \text { - Поширення результатів } \\
2450 \text { - Загальні висновки } \\
2500 \text { - Моніторинг подальших заходів } \\
2600 \text { - Звітування про прийняття ризику }\end{array}$ \\
\hline
\end{tabular}

Обробка інформації на етапі планування майбутньої перевірки внутрішніми аудиторами проводиться для забезпечення управління функцією внутрішнього аудиту. В основу банківської діяльності покладені ризики, а саме функція внутрішнього аудиту встановлює та оцінює процес управління ризиками для задоволення ризик-апетиту банку. Визначаються ризики діяльності банку на основі яких формується перелік об'єктів перевірки у робочій програмі завдання. Для формування програми аудиторського завдання керівнику внутрішнього аудиту необхідно визначити ресурси, цілі та обсяг робіт і організувати обмін інформацією. Ефективне планування та організація стане основою для якісного здійснення аудиторського завдання та забезпечить виконання плану. Цінність внутрішнього аудиту полягає у сприянні удосконаленню процесів корпоративного управління, управління ризиками та контролю в банку.

Етап виконання аудиторського завдання забезпечується підрозділом внутрішнього аудиту на чолі з керівником. Внутрішні аудитори повинні документально оформлювати інформацію для досягнення цілей завдання. В ході перевірки аудитори розробляють та формують робочі документи, які надають наглядне документальне підтвердження ви- 
явлених фактів порушення та є аудиторськими доказами. Робочі документи аудиторського завдання оформлюються внутрішніми аудиторами під час здійснення аудиторської перевірки. Робоча документація - це сукупність документів, які використовуються внутрішніми аудиторами під час виконання аудиторського завдання та слугують аудиторськими доказами при формуванні думки i складанні Аудиторського звіту. Документи, що пов'язані 3 проведенням аудиту містять інформацію про операції у відповідності предмету перевірки. Інформація може міститись на електронних та паперових носіях і може становити комерційну таємницю. Збереження сформованих у справу робочих документів забезпечується відповідно до чиного законодавства України та внутрішніх нормативних актів банку. Зберігаються робочі документи у підрозділі внутрішнього аудиту згідно термінів, які встановлені внутрішніми положеннями, а потім передаються до архіву. Робочі документи, після спливу терміну зберігання, знищуються, або це може відбуватися за ініціативою керівника підрозділу внутрішнього аудиту. Повідомлення про знищення документації зберігається у підрозділі. Керівник контролює ведення реєстру усіх документів. Отримана інформація про об'єкт аналізується та оцінюється на ймовірність ризиків та їх суттєвості для діяльності банку. Для отримання доказів виконуються аудиторські процедури. Всі результати аудиту фіксуються у таблицях, тестах, анкетах, тощо. Підтверджені результати формулюють висновки аудиторського завдання, що містяться у звіті. Якісну роботу забезпечить кваліфікований аудиторський персонал, що залежить від їх професійної компетенції. На керівника внутрішнього аудиту покладається функція контролю за виконанням завдання.

Результативний етап характеризується завершенням завдання та формуванням результатів. Виявлені порушення узагальнюються i систематизуються, розробляються рекомендації та пропозиції, які формуються у звіті та висновках внутрішнього аудиту. Попередньо складається проект аудиторського звіту та план заходів щодо усунення виявлених порушень, недоліків та виконання рекомендацій за результатами аудиторської перевірки для ознайомлення, обговорення та внесення коректив відповідальними особами. Документально погоджені результати пе- ревірки оформлюються в аудиторському звіті. Аудиторський звіт відображає результати аудиторської перевірки та формує висновки i рекомендації щодо усунення виявлених недоліків та порушень, мінімізації рівня ризиків, покращення системи внутрішнього контролю банківської діяльності. До якісних характеристик звіту можна віднести точність, об'єктивні, своєчасність, чіткість та зрозумілість інформації, що формує незалежну і неупереджену думку внутрішнього аудиту та показує досягнення цілей завдання. Висновок підтверджується отриманими фактами та доказами і враховує стратегічні цілі, очікування й ризики банку. Керівник внутрішнього аудиту звітує про результати завдання вищому виконавчому керівництву та раді банку. Внутрішніми аудиторами здійснюють моніторинг дій та заходів по усуненню порушень та недоліків, тим самим виконуючи функцію контролю за наданими пропозиціями та рекомендаціями.

За вищезазначеною інформацію можемо сформувати документи у відповідності до етапів, які фіксують результати діяльності внутрішнього аудиту (табл. 2).

Діяльність підрозділу внутрішнього аудиту регулюється внутрішніми документами банку у яких слід чітко прописувати форми документів для фіксації результатів. Розробити методику заповнення документів та визначення уніфікованого підходу до організації робочого процесу згідно Міжнародних стандартів професійної практики внутрішнього аудиту. При створенні типових форм, відповідність єдиній структурі буде прослідковуватися єдиний підхід до відображення інформації та у подальшому іiі трактування користувачами. У подальшому внутрішній аудит забезпечує стратегічне управління банком.

Надалі результати роботи підрозділу внутрішнього аудиту можуть використовувати зовнішні аудитори для отримання аудиторських доказів, згідно МСА 610 «Використання роботи внутрішніх аудиторів» [4]. Оцінку підрозділу внутрішнього аудиту зовнішній аудитор надає оцінюючи: політики та процедури підрозділу, підтвердження об'єктивності і компетентності внутрішніх аудиторів застосовуючи професійні судження, систематичний підхід, включаючи контроль якості. Зовнішній аудитор вивчає звіти про результати роботи підрозділу внутрішнього аудиту, яку планується використати для оцінки обсягу аудиторських процедур. 
Т а б ли ц я 2

Перелік документів фіксації результатів діяльності внутрішнього аудиту

\begin{tabular}{|c|c|c|}
\hline Етапи & Документи & Призначення \\
\hline Планування & $\begin{array}{l}\text { - Ризик-орієнтований план; } \\
\text { - Робоча програма завдання; } \\
\text { - Повідомлення про проведення перевірки; } \\
\text { - Запит на отримання документів для планування. }\end{array}$ & $\begin{array}{l}\text { Складання плану на основі } \\
\text { оцінки ризиків, визначення } \\
\text { процедур збору, оцінки } \\
\text { аудиторського завдання. }\end{array}$ \\
\hline $\begin{array}{l}\text { Виконання } \\
\text { аудиторського } \\
\text { завдання }\end{array}$ & $\begin{array}{l}\text { - Запит на отримання документів для виконання } \\
\text { завдання; } \\
\text { - Документи за операціями згідно предмету аудиту; } \\
\text { - Анкети аудиторської перевірки; } \\
\text { - Тести контролю; } \\
\text { - Інші робочі документи. }\end{array}$ & $\begin{array}{l}\text { Фіксація аудиторських } \\
\text { доказів. }\end{array}$ \\
\hline Результативний & $\begin{array}{l}\text { - План заходів щодо усунення виявлених порушень, } \\
\text { недоліків та виконання рекомендацій; } \\
\text { - Аудиторський звіт; } \\
\text { - Звіт про виконання пропозицій та плану заходів за } \\
\text { результатами перевірки. }\end{array}$ & $\begin{array}{l}\text { Узагальнення результатів } \\
\text { аудиторського завдання, } \\
\text { розробка заходів щодо усу- } \\
\text { нення виявлених порушень } \\
\text { та контроль їх виконання. }\end{array}$ \\
\hline
\end{tabular}

Джерело: розроблено автором на підставі [5]

Аудиторські процедури зовнішніх аудиторів щодо роботи підрозділу внутрішнього аудиту включають інформацію про відповідність планів та їх належного виконання, достатній обсяг доказів, які дали змогу дійти до обгрунтованих висновків, звіти, складені у відповідності результатам виконаної роботи підрозділом внутрішнього аудиту.

Також зовнішніми аудиторами може використовуватись пряма допомога внутрішніх аудиторів для виконання аудиторських процедур під їх керівництвом та наглядом 3 подальшою перевіркою роботи. Внутрішні аудитори повинні гарантувати конфіденційність інформації та повідомляти про будь-які загрози щодо об'єктивності виконання завдання.

Висновки та перспективи подалыших досліджень. Внутрішні аудитори несуть відповідальність за відповідність Міжнародним стандартам професійної практики внутрішнього аудиту. Фіксації результатів діяльності внутрішнього аудиту відбувається за допомогою документування. Етап планування характерний документи, які забезпечать розробку робочої програми завдання. На етапі виконання аудиторського завдання розробляються робочі документи аудитори, які фіксують отримання аудиторських доказів для подальшого формування висновків та розробки рекомендацій. На результативному етапі розробляються документи, що узагальнюють результати виконаного аудиторського завдання. Основним документом даного етапу є аудиторський звіт. Професійні судження, об'єктивність та компетентність внутрішніх аудиторів підвищує довіру до підрозділу внутрішнього аудиту i 3 боку зовнішніх аудиторів. Останні можуть викори- стовувати роботу внутрішніх аудиторів або залучати їх до прямої допомоги при виконанні аудиторських процедур. Для цього зовнішній аудитор здійснює оцінку підрозділу внутрішнього аудиту.

\section{Література}

1. Білокінь Г. М. Становлення і вдосконалення аудиторської служби в банках України: автореф. дис... канд. екон. наук: 08.06.04 / Білокінь Ганна Миколаївна ; Київський національний економічний ун-т. - К., 2005. - 20 с.

2. Каменська T. О. Внутрішній аудит: методологія та організація: автореф. дис. ... д-ра екон. наук : 08.00.09 / Каменська Тетяна Олександрівна ; Нац. акад. статистики, обліку та аудиту. $-\mathrm{K}, 2011 .-40 \mathrm{c}$.

3. Маркевич М. А. Організація і методика внутрішнього аудиту в банку: автореф. дис. ... канд. екон. наук : 08.00.09 / Маркевич Микола Андрійович ; Одес. держ. екон. ун-т. - Одеса, 2011. -20 c.

4. Міжнародні стандарти контролю якості, аудиту, огляду, іншого надання впевненості та супутніх послуг: Вид. 2016-2017 pp. Ч.І: пер. 3 англ. - Київ: Міжнар. Федерація бухгалтерів: Аудит. палата України, 2018. - 1141 с.

5. Міжнародні стандарти професійної практики внутрішнього аудиту (стандарти), редакція 2017 року [Електронний ресурс]. - Режим доступу: https://www.iia.org.ua/

6. Петренко С. М. Внутрішній контроль діяльності підприємств і його інформаційне забезпечення: теорія, методологія, організація: автореф. дис. ... д-ра екон. наук : 08.00.09 / Петренко Світлана Миколаївна ; Держ. акад. статистики, 
обліку та аудиту Держкомстату України. - К., 2010. -36 c.

7. Письменна М. С. Внутрішній аудит в банківській системі: дис. ... канд. екон. наук : 08.00.09 / Письменна Марія Сергіївна ; Одес. держ. екон. ун-т. - Одеса, 2011. - 265 с.

8. Проскуріна H. М. Розвиток процедур аудиту: теорія та методологія: автореф. дис. ... дра екон. наук : 08.00.09 / Проскуріна Неля Миколаївна; Держ. служба статистики України, Нац. акад. статистики, обліку та аудиту. - К., 2012. $38 \mathrm{c}$.

9. Сафонов Т. I. Документувння результатів роботи внутрішнього аудиту / T. I. Сафонов // Науково-практичне видання «Незалежний АУДИТОР». - 2014. - № 9(III). - С. 89-95.

10. Скаско О. I. Теорія, методологія та організація системи контролю в банках України: автореф. дис. ... д-ра екон. наук: 08.00.09 / О. І. Скаско; Терноп. нац. екон. ун-т. - Тернопіль, 2014. -40 c.

11. Сметанко О. В. Документування роботи служби внутрішнього аудиту / О. В. Сметанко // Економічні науки. Сер. Облік і фінанси. 2010. - Вип. 7, Ч. 5. - С. 304-312.

12. Сурніна К. С. Аналітичні процедури в аудиті: методологія та організація : автореф. дис ... д-ра екон. наук: 08.00.09 / К. С. Сурніна - Київ, $2012 .-35 \mathrm{c}$.

13. Філозоп О. В. Розвиток внутрішнього аудиту в Україні: організація і методика: автореф. дис. ... канд. екон. наук : 08.00.09 / Філозоп Олег Володимирович ; Житомир. держ. технол. ун-т. Житомир, 2010. - 20 с.

\section{References}

1. Bilokin, G. M. (2005). Becoming and improvement of public accountant service in the banks of Ukraine. The dissertation on gaining of the scientific degree of Candidate of Economic Science, speciality 08.06.04. Accounting, analysis and audit. Kyiv: Kyiv National Economic University.

2. Kamenska, T. O. (2011). Internal auditing: methodology and organization. Doctoral candidate's thesis in economical studies specialized in 08.00.09 Accountancy, analysis and auditing (for types of the economical activities). Kiev: National Academy of Statistics, Accounting and Auditing.

3. Markevych, M. A. (2011). Organization and methods of internal auditing in the bank. The dissertation for the degree of Candidate of Economic Sciences, specialty 08.00.09 Accounting, Analysis

Стаття надійшла

до редакції : 11.05 .2019 p. and Auditing (by types of economic activity). Odessa State Economic University, Odessa.

4. Handbook of International Quality Control, Auditing, Review, Other Assurance, and Related Services Pronouncements: 2016-2017 Edition. (2018). Volume I. International Auditing and Assurance Standards Board. International Federation of Accountants, 1141.

5. International Standards for the Professional Practice of Internal Auditing. The Institute of Internal Auditors. (2017). Retrieved from: https://www.iia.org.ua.

6. Petrenko, S. M. (2010). Internal control of activity of enterprises and its informative providing: theory, methodology, organization. Thesis for obtaining the scientific degree of Doctor of Economic sciences at the specialty 08.00.09 - accounting, analysis and auditing (according to the type of economic activity). Kyiv: State Academy of Statistics, Accounting and Auditing of the State Committee of Statistics of Ukrainian.

7. Pysmenna, M. S. (2011). Internal Audit in the Banking System: diss. Candidate econ Sciences: 08.00.09; Odessa state econ. Odessa, 265.

8. Proskurina, N. M. (2012). Development of audit procedures: theory and methodology: author's abstract. dis ... Dr. Econ. Sciences: 08.00.09; The state Statistics Service of Ukraine, National acad. statistics, accounting and auditing. Kyiv, 38 .

9. Safonov, T. I. (2014). Documentation of Internal Audit Results. Scientific and Practical Edition of "Independent Auditor", 9, 89-95.

10. Skasko, O. I. (2014). Theory, methodology and organization of control system in banks of Ukraine: author's abstract. dis ... Dr. Econ. Sciences: 08.00.09. Ternopil, 40.

11. Smetanko, O. V. (2010). Documentation of the work of the Internal Audit Service. Economic sciences. Accounting and finance, 7, 304-312.

12. Surnina, K. S. (2012). Analytical procedures in auditing: methodology and organization. Dissertation on the receipt of scientific degree of doctor of economic sciences after speciality 08.00 .09 is a record-keeping and audit (after the types of economic activity). Kyiv: National academy of statistics, account and audit.

13. Filozop, O. V. (2010). Development of Internal Audit in Ukraine: Organization and Methods. Thesis for obtaining the scientific degree of candidate of economic sciences by specialty 08.00.09 Accounting, Analysis and Auditing (by types of economic activity). Zhytomyr State Technological University, Zhytomyr.

\footnotetext{
Стаття прийнята

до друку: 26.06.2019 p.
}

Бібліографічний опис для цитування :

Долінська О. М. Документування результатів діяльності внутрішнього аудиту банку / О. М. Долінська // Часопис економічних реформ. - 2019. - № 2 (34). - С. 54-60. 